\title{
Editorial
}

\section{Predicting Severity in Acute Pancreatitis: A Never-Ending Quest...}

\author{
Carina Leal ${ }^{\mathrm{a}}$ Nuno Almeida ${ }^{\mathrm{b}}$ \\ ${ }^{a}$ Gastroenterology Department, Centro Hospitalar de Leiria, Leiria, Portugal; \\ ${ }^{b}$ Gastroenterology Department, Centro Hospitalar e Universitário de Coimbra, Coimbra, Portugal
}

Keywords

Pancreatitis $\cdot$ C-reactive protein $\cdot$ Classification

\section{Factores preditivos de gravidade na pancreatite aguda: uma busca interminável...}

\section{Palavras Chave}

Pancreatite · Proteina $C$ reativa $\cdot$ Classificação

Acute pancreatitis (AP) is one of the leading causes of hospital admission of gastrointestinal origin, with a reported annual incidence ranging from 4.6 to 100 per 100,000 in Europe [1]. Its incidence appears to be rising, with a median increase of $3.4 \%$ per year [1], most likely due to the obesity epidemic and its relationship with gallstones.

The revised Atlanta classification [2] divides this entity into interstitial edematous and necrotizing AP, based on the absence or presence of tissue necrosis. Furthermore, the disease is graded according to its severity into mild, moderate, and severe. This classification relies on the presence of organ failure (transient or persistent) and local or systemic complications. The definite grade of severity requires reassessment, which is advisable at $24 \mathrm{~h}$, $48 \mathrm{~h}$, and 7 days after admission.

\section{KARGER}

E-Mail karger@karger.com www.karger.com/pjg
(C) 2019 Sociedade Portuguesa de Gastrenterologia Published by S. Karger AG, Basel

Karcer

Open access

This article is licensed under the Creative Commons AttributionNonCommercial-NoDerivatives 4.0 International License (CC BYNC-ND) (http://www.karger.com/Services/OpenAccessLicense). Usage and distribution for commercial purposes as well as any distribution of modified material requires written permission.
The importance of severity prediction is well established. A precise assessment of severity would downsize the financial burden of AP, as mild AP does not require inpatient treatment or pancreatic imaging. Also, it is expected to decrease mortality and morbidity, as it would aid in the triage for intensive care units.

Accurately defining and predicting the severity of the disease early on in its course has historically been a daunting task. Multiple scoring systems have been developed based on clinical, laboratory, and radiologic findings. Most models are based on data from two points in time (i.e., at admission and $48 \mathrm{~h}$ ), rendering them impossible to use in a triage setting. Other scoring systems are timeconsuming, making it difficult to implement them in the emergency department. Moreover, most algorithms have failed to achieve reasonable predictive values [3].

Probably one of the most recognized scoring systems, Ranson's criteria, requires parameters assessed at admission and at $48 \mathrm{~h}$ and, although still widely used, it is a poor predictor of severity [4]. The Imrie or Glasgow score is a simplified version of Ranson's criteria but has the same disadvantages. The Bedside Index of Severity in Acute Pancreatitis (BISAP) score is easy to use and incorporates

All authors contributed equally to this work. 
the systemic inflammatory response syndrome (SIRS) criteria, but has only been validated for mortality prediction $[4,5]$. The Harmless Acute Pancreatitis Score (HAPS) only requires three parameters and was developed to identify those with nonsevere AP [6]. Originally developed in the 90s, the Balthazar score or computerized tomography severity index takes into account the presence of inflammation and fluid collections as well as the percentage of tissue necrosis [7]. Lastly, two scoring systems developed in critically ill patients were shown to be useful in AP. The Acute Physiology and Chronic Health Examination (APACHE), especially APACHE II, has a good negative predictive value for severe AP [8], but it is cumbersome to use and whether it reflects the presence of tissue necrosis is a matter of debate. The SIRS score is already incorporated in other scoring systems and seems to have an independent value in predicting organ failure and mortality [9]. Concerning AP severity, multiple individual laboratory markers have been studied. The most convincing ones are $\mathrm{C}$-reactive protein $(\mathrm{CRP})$, blood urea nitrogen, and serum creatinine [10-12].

In this issue of GE - Portuguese Journal of Gastroenterology, Kayar et al. [13] present their work on "Prediction of self-limited acute pancreatitis cases at admission to emergency unit." The authors looked at biochemical markers as predictors of mild AP with the ultimate goal of identifying patients suited for outpatient care. In this prospective study, 180 patients with mild AP according to HAPS and Imrie scores were selected and submitted to CT scans and blood tests at 12 and $72 \mathrm{~h}$. The patients were then graded according to the Balthazar score (A-E), and the most relevant biomarkers (amylase, lipase, and CRP) were recorded.

A correlation was found between CT scores and amylase values on days 1 and 3 and CRP values on day 3 ( $p=$ 0.001 ). The authors then sought to determine cutoff values that would differentiate patients with higher CT scores, that is, with peripancreatic fluid collections and a more severe disease. The optimal cutoff point for amylase on day 1 was $1,360 \mathrm{U} / \mathrm{L}$ (with a positive predictive value of $62 \%$ ), for amylase on day 3 it was $135 \mathrm{U} / \mathrm{L}$ (with a positive predictive value of 59\%), and for CRP on day 3 it was $8.7 \mathrm{mg} / \mathrm{dL}$ (with a positive predictive value of 66\%). Of note, no statistical difference was found between CT scans performed at 12 and $72 \mathrm{~h}$ and it should be emphasized that none of the patients with CT scores A-B progressed to stage $\mathrm{E}$. These findings support the early discharge of such patients.

However, the results and conclusions presented by the authors have several limitations: the majority of patients enrolled had AP of biliary origin; the follow-up of these patients appears to be short; and the presence and extent of pancreatic and peripancreatic necrosis may not be defined clearly on imaging during the first few days of disease, raising questions about the timing of radiologic reevaluation.

The finding of a correlation between lipase and amylase levels and the severity of AP challenges our current view on the disease. However, it should be noted that, in this study, due to subgroup analysis and smaller sample size, the standard deviation approaches mean values. Currently, evidence states that lipase and amylase levels are unable to determine the severity and etiology of pancreatitis. There are few studies that advocate the opposite, the one by Nordestgaard et al. [14] being the most cited. An exception is the pediatric population, since a study by Coffey et al. [15] suggests a potential role for lipase within the first $24 \mathrm{~h}$ as predictor of severity.

The same methodological considerations can be applied to the results regarding CRP in this study. The use of CRP as a predictor of severity has long been supported and has been previously addressed in a study by Cardoso et al. [16]. CRP levels at $24 \mathrm{~h}$ showed good individual prognostic accuracy for in-hospital survival. This conclusion follows other studies, though ideal cutoff points remain to be determined [17]. Furthermore, a recent Cochrane review failed to determine the role of CRP in the diagnosis of pancreatic necrosis [18]. Currently, guidelines advise against the use of a single biomarker to triage patients, but CRP levels $\geq 150 \mathrm{mg} / \mathrm{dL}$ at $48 \mathrm{~h}$ are accepted as a predictor of worse prognosis.

The correct management of patients with AP remains a challenge for clinicians, and no scoring system has consistently proven to be superior $[17,19]$. Early identification of organ failure and complications seems to be the key to shed some light on an otherwise unknown disease course. A well-designed, prospective study that incorporates the most used biomarkers as well as imaging and easy-to-apply scores is undeniably needed.

\section{Disclosure Statement}

The authors have no conflicts of interest to declare.

Funding Sources

No funding was received. 


\section{References}

1 Roberts SE, Morrison-Rees S, John A, Williams JG, Brown TH, Samuel DG. The incidence and aetiology of acute pancreatitis across Europe. Pancreatology. 2017 Mar Apr;17(2):155-65.

2 Banks PA, Bollen TL, Dervenis C, Gooszen HG, Johnson CD, Sarr MG, et al.; Acute Pancreatitis Classification Working Group. Classification of acute pancreatitis-2012: revision of the Atlanta classification and definitions by international consensus. Gut. 2013 Jan;62(1):102-11.

3 Robert JH, Frossard JL, Mermillod B, Soravia C, Mensi N, Roth M, et al. Early prediction of acute pancreatitis: prospective study comparing computed tomography scans, Ranson, Glascow, Acute Physiology and Chronic Health Evaluation II scores, and various serum markers. World J Surg. 2002 May;26(5): 612-9.

4 Papachristou GI, Muddana V, Yadav D, O'Connell M, Sanders MK, Slivka A, et al. Comparison of BISAP, Ranson's, APACHEII, and CTSI scores in predicting organ failure, complications, and mortality in acute pancreatitis. Am J Gastroenterol. 2010 Feb; 105(2):435-41.

5 Gao W, Yang HX, Ma CE. The Value of BISAP Score for Predicting Mortality and Severity in Acute Pancreatitis: A Systematic Review and Meta-Analysis. PLoS One. 2015 Jun; 10(6):e0130412.

6 Lankisch PG, Weber-Dany B, Hebel K, Maisonneuve $\mathrm{P}$, Lowenfels $\mathrm{AB}$. The harmless acute pancreatitis score: a clinical algorithm for rapid initial stratification of nonsevere disease. Clin Gastroenterol Hepatol. 2009 Jun;7(6):702-5.

7 Balthazar EJ, Robinson DL, Megibow AJ, Ranson JH. Acute pancreatitis: value of CT in establishing prognosis. Radiology. 1990 Feb; 174(2):331-6.

8 Zhang J, Shahbaz M, Fang R, Liang B, Gao C, $\mathrm{Gao} \mathrm{H}$, et al. Comparison of the BISAP scores for predicting the severity of acute pancreatitis in Chinese patients according to the latest Atlanta classification. J Hepatobiliary Pancreat Sci. 2014 Sep;21(9):689-94.

9 Singh VK, Wu BU, Bollen TL, Repas K, Maurer R, Mortele KJ, et al. Early systemic inflammatory response syndrome is associated with severe acute pancreatitis. Clin Gastroenterol Hepatol. 2009 Nov;7(11):1247-51.

10 Pongprasobchai S, Jianjaroonwong V, Charatcharoenwitthaya P, Komoltri C, Tanwandee T, Leelakusolvong S, et al. Erythrocyte sedimentation rate and C-reactive protein for the prediction of severity of acute pancreatitis. Pancreas. 2010 Nov;39(8):1226-30.

11 Wu BU, Bakker OJ, Papachristou GI, Besselink MG, Repas K, van Santvoort HC, et al. Blood urea nitrogen in the early assessment of acute pancreatitis: an international validation study. Arch Intern Med. 2011 Apr;171(7): 669-76.

12 Lankisch PG, Weber-Dany B, Maisonneuve $\mathrm{P}$, Lowenfels $\mathrm{AB}$. High serum creatinine in acute pancreatitis: a marker for pancreatic necrosis? Am J Gastroenterol. 2010 May;105(5): 1196-200.
13 Kayar Y, Senturk H, Tozlu M, Baysal B, Atay M, Ince AT. Prediction of Self-Limited Acute Pancreatitis Cases at Admission to Emergency Unit. GE Port J Gastroenterol. doi: $10.1159 / 000493762$.

14 Nordestgaard AG, Wilson SE, Williams RA. Correlation of serum amylase levels with pancreatic pathology and pancreatitis etiology. Pancreas. 1988;3(2):159-61.

15 Coffey MJ, Nightingale S, Ooi CY. Serum lipase as an early predictor of severity in pediatric acute pancreatitis. J Pediatr Gastroenterol Nutr. 2013 Jun;56(6):602-8.

16 Cardoso FS, Ricardo LB, Oliveira AM, Horta DV, Papoila AL, Deus JR, et al. C-Reactive Protein at 24 Hours after Hospital Admission may have Relevant Prognostic Accuracy in Acute Pancreatitis: A Retrospective Cohort Study. GE Port J Gastroenterol. 2015 Apr; 22(5): 198-203.

17 Cho JH, Kim TN, Chung HH, Kim KH. Comparison of scoring systems in predicting the severity of acute pancreatitis. World J Gastroenterol. 2015 Feb;21(8):2387-94.

18 Komolafe O, Pereira SP, Davidson BR, Gurusamy KS. Serum C-reactive protein, procalcitonin, and lactate dehydrogenase for the diagnosis of pancreatic necrosis. Cochrane Database Syst Rev. 2017 Apr;4(4):CD012645.

19 Bollen TL, Singh VK, Maurer R, Repas K, van Es HW, Banks PA, et al. A comparative evaluation of radiologic and clinical scoring systems in the early prediction of severity in acute pancreatitis. Am J Gastroenterol. 2012 Apr;107(4):612-9. 